\title{
The effect of lipid saturation on nutrient digestibility of layer diets
}

\author{
E.J. King1 ${ }^{1}$ F.H. de Witt ${ }^{1 \#}$, H.J. van der Merwe ${ }^{1}$, A. Hugo ${ }^{2}$ \& M.D. Fair ${ }^{1}$ \\ ${ }^{1}$ Department of Animal, Wildlife and Grassland Science \\ ${ }^{2}$ Department of Microbial, Biochemical and Food Biotechnology \\ P.O. Box 339, University of the Free State, Bloemfontein 9300, South Africa
}

(Received 8 December 2012; Accepted 26 September 2013; First published online 11 October 2013)

\begin{abstract}
Copyright resides with the authors in terms of the Creative Commons Attribution 2.5 South African Licence. See:
http://creativecommons.org/licenses/by/2.5/za/Condition of use: The user may copy, distribute, transmit and adapt the work, but must recognise the authors and the South African Journal of Animal Science
\end{abstract}

\begin{abstract}
A study was conducted to investigate the effect of dietary lipid saturation on nutrient digestibility of layer diets. Five isoenergetic (12.6 MJ AME/kg DM) and isonitrogenous (170 g CP/kg DM) diets were formulated using different lipid sources at a constant $30 \mathrm{~g} / \mathrm{kg}$ inclusion level. The control $\mathrm{n}-3$ diet was formulated using a blend (50:50) of linseed- and fish oil, while fish oil (polyunsaturated n-3), sunflower oil (polyunsaturated n-6), high oleic acid (HO) sunflower oil (monounsaturated n-9) and tallow (saturated fatty acid) were used as other supplementary lipid sources. The five dietary treatments were randomly allocated to the two hundred (200) individually caged Hy-Line Silver-Brown laying hens (20 weeks of age) $(\mathrm{n}=$ 40/treatment). Experimental diets were provided to the birds on an ad libitum basis for a 22 week period (from 20 to 42 weeks of age). At 42 weeks of age, six hens per treatment ( $\mathrm{n}=6$ replicates/treatment), were randomly selected to partake in a digestibility study over a 7 day period using the total collection technique. The polyunsaturated n- 6 treatment resulted in the lowest crude protein digestibility, whereas the saturated fatty acid treatment resulted in the lowest fat digestibility. Furthermore, the polyunsaturated n-3 diet resulted in the highest dietary AME (13.29 MJ/kg DM) and $\mathrm{AME}_{\mathrm{n}}(12.74 \mathrm{MJ} / \mathrm{kg} \mathrm{DM})$ content.
\end{abstract}

Keywords: Apparent metabolizable energy, feed intake, mono-, polyunsaturated fatty acids

\#Corresponding author: dewittfh@ufs.ac.za

\section{Introduction}

Although supplementary lipid sources generally increases energy utilisation of the basal diet (Mateos \& Sell, 1980), these lipid sources do differ in terms of their digestibility efficiencies. Jorgensen et al. (2008) indicated that factors such as the fatty acid chain length, unsaturated to saturated fatty acid ratio, degree of esterification, the position of fatty acids on the glycerol molecule, as well as dietary crude protein, -fat and fibre content, could work synergistically to influence the apparent digestibility of lipid sources. Although the digestion of lipids in poultry is mainly dependent on bile salt and lipase enzyme secretion, bird age is another aspect that influences lipid digestion in poultry. Wiseman \& Lessire (1987) illustrated that the concentration of bile salts could be a limiting factor in micelle formation when young birds are fed diets high in unsaturated fatty acids.

Leeson \& Summers (2001) indicated that the digestibility of lipid sources differ significantly; varying from $70 \%$ for tallow to $96 \%$ for soybean- and menhaden fish oil. Disparities in the digestibility of individual fatty acids vary significantly as well, from $2 \%$ for palmitic acid up to $95 \%$ for linoleic acid depending on the age of the birds (Leeson \& Summers, 2001). Other authors (Zollitsch et al., 1997; Honda et al., 2009) concluded that a decrease in fatty acid saturation resulted in an improved fatty acid digestibility and that an increase in the unsaturated fatty acid (UFA) content of lipid sources would consequently result in a higher metabolisable energy value. However, nutrient digestibility is not only influenced by dietary lipid saturation, but also by dietary lipid inclusion levels. Excessive fat inclusion levels (8\% to 10\%) have a suppressing 
effect on protein and carbohydrate digestion in the ileum of chickens (Honda et al., 2009) due to its suppressive effects on pancreatic enzyme secretion such as protease and amylase.

Leeson \& Summers (2001) suggested that most of the variation in documented studies could be ascribed to diets that are not isoenergetic and differences in lipid inclusion levels. Considering the renewed interest in the fatty acid enrichment of eggs, as well as the contradictory information regarding the effect of dietary fatty acid profile on lipid digestibility, the need arises to determine the digestibility of isoenergetic diets, differing in lipid saturation.

The aim of the present study was therefore to determine the effect of dietary lipid saturation on nutrient digestibility of laying hens at 42 weeks of age.

\section{Materials and Methods}

Five isoenergetic (12.6 MJ AME/kg DM) and isonitrogenous (170 g CP/kg DM) diets were formulated using various supplementary lipid sources at $30 \mathrm{~g} / \mathrm{kg}$ inclusion level to manipulate dietary fatty acid saturation levels. The control diet was formulated using a blend $(50: 50)$ of linseed- and fish oil, while fish oil was used in the polyunsaturated n-3 (PUFA n-3) treatment. In the polyunsaturated n-6 diet (PUFA n-6), sunflower oil was used, whereas high oleic acid sunflower oil was used as supplementary lipid source in the monounsaturated n-9 diet (MUFA n-9). Lastly, tallow was used as lipid source in the saturated fatty acid (SFA) treatment. The five dietary treatments were randomly allocated to the two hundred (200) individually caged Hy-Line Silver-Brown laying hens (20 weeks of age) (n = 40/treatment). Experimental diets were provided to the birds on an ad libitum basis for a 22 week period (from 20 to 42 weeks of age), and birds had free access to water by means of individual drinker nipples. At the onset of 42 weeks of age, six hens per treatment $(n=6 /$ treatment) were randomly selected to partake in a digestibility study over a seven (7) day collection period by means of the total collection method (Larbier \& Leclercq, 1994). Composite feed, feed refusal and excreta samples were dried and milled (Dozier et al., 2008) before represented samples were taken for chemical analysis according to the procedures described by the AOAC (2000). Mean feed intake and excreta weights for the seven day collection period (between weeks 42 to 43 of age) were used for the calculation of gross energy intake and excretion to equate the apparent metabolisable energy (AME) of the diets. The AME value was corrected for nitrogen equilibrium by assuming that excreta nitrogen, as a consequence of tissue nitrogen catabolism, has an energy value of $34.4 \mathrm{~kJ} / \mathrm{g}$ (Leeson \& Summers, 2001). The apparent diet digestibility was calculated according to the formulas of Dhanoa et al. (2008). The fatty acid methyl esters (FAME) of the experimental diets (Table 2) were determined by extracting the fat content thereof using the method firstly described by Folch et al. (1957). Data was statistically analysed using a completely fully randomized one-way design. The PROC ANOVA procedures of the Statistical Analysis System $\left(\right.$ SAS $^{\circledR}$ ) program (SAS, 2010) were used to test for significant differences between treatment means at the probabilities of $P<0.05, P<0.01$ and $P<0.001$, while the Tukey's honest significant difference (HSD) test, was used to separate treatment means.

\section{Results and Discussions}

Experimental diets analysed (Table 1) on average about 8.9\% higher for crude protein (CP) when compared to the formulated composition, while it is noticeable to mention the differences in the mean dietary fatty acid methyl esters (FAME) of the experimental diets (Table 2). These differences in dietary FAME could be related to the FAME profile of the respective dietary lipid sources used in supplementing the diets.

Dietary lipid saturation level had no effect $(P \geq 0.50)$ on feed intake or apparent digestibility of organic matter as indicated in Table 3.The polyunsaturated n- 6 diet resulted in the lowest $(P<0.05)$ CP digestibility (55.0\%), while all the unsaturated fatty acid (UFA) diets (combination of mono and polyunsaturated diets) had a higher $(P<0.0001)$ fat digestibility (ranging from $94.2 \%$ to $95.6 \%)$ compared to that of the saturated (SFA) treatment $(90.4 \%)$. Furthermore, the polyunsaturated n-3 diet resulted in both the highest $(P<0.01)$ dietary AME (13.3 MJ/kg DM) and $\mathrm{AME}_{\mathrm{n}}(12.7 \mathrm{MJ} / \mathrm{kg} \mathrm{DM})$, while the polyunsaturated $\mathrm{n}-6$ diet resulted in the lowest AME (12.9 MJ/kg DM) and $\mathrm{AME}_{\mathrm{n}}(12.4 \mathrm{MJ} / \mathrm{kg} \mathrm{DM})$ content.

Results of the fat digestibility are in agreement with that of Smink et al. (2008), who reported that UFAs are known for their higher digestibility coefficients and absorption efficiencies of lipids, compared to that of SFAs. One of the explanations for these findings is the fact that mono-glycerides and long chain UFAs have the ability to link up with conjugated bile salts to form micelles which increases their ability to 
Table1 Mean dry matter chemical analysis of experimental diets used in the digestibility study

\begin{tabular}{lccccc}
\hline & Control & $\begin{array}{c}\text { Polyunsaturated } \\
(\mathrm{n}-3)\end{array}$ & $\begin{array}{c}\text { Polyunsaturated } \\
(\mathrm{n}-6)\end{array}$ & $\begin{array}{c}\text { Monounsaturated } \\
(\mathrm{n}-9)\end{array}$ & $\begin{array}{c}\text { Saturated } \\
(\mathrm{SFA})\end{array}$ \\
\hline & & & & & \\
Dry matter (g/kg) & 953.4 & 952.9 & 953.6 & 960.3 & 956.0 \\
Gross energy (MJ/kg) & 165.7 & 166.9 & 164.5 & 166.4 & 166.8 \\
Crude protein (g/kg) & 194.2 & 181.0 & 188.0 & 177.5 & 189.6 \\
Fat (g/kg) & 56.3 & 58.0 & 57.5 & 57.7 & 57.6 \\
Ash (g/kg) & 143.5 & 142.6 & 147.6 & 144.1 & 145.9 \\
\hline
\end{tabular}

Table 2 Mean fatty acid methyl esters (FAME ${ }^{\#}$ ) profile of layer diets used during the digestibility study (42 weeks of age)

\begin{tabular}{lrcccc}
\hline & Control & $\begin{array}{c}\text { Polyunsaturated } \\
(\mathrm{n}-3)\end{array}$ & $\begin{array}{c}\text { Polyunsaturated } \\
(\mathrm{n}-6)\end{array}$ & $\begin{array}{c}\text { Monounsaturated } \\
(\mathrm{n}-9)\end{array}$ & Saturated \\
\hline FAME\# $^{\#}$ (\%) & & & & & \\
$\quad$ Myristic acid & 2.39 & 5.22 & 0.05 & - & 2.01 \\
Palmitic acid & 13.03 & 18.18 & 9.14 & 7.56 & 19.99 \\
Stearic acid & 3.36 & 3.47 & 4.56 & 4.47 & 17.11 \\
Oleic acid & 23.19 & 21.32 & 27.82 & 54.86 & 30.24 \\
Linoleic acid & 29.96 & 27.09 & 55.27 & 29.88 & 24.04 \\
$\alpha$-Linolenic acid & 15.38 & 1.13 & 0.84 & 0.77 & 0.95 \\
Eicosopentaenoic acid & 4.26 & 8.17 & - & - & - \\
Docosapentaenoic acid & 0.41 & 0.66 & - & - & - \\
Docosahexanoic acid & 1.38 & 2.57 & - & - & - \\
\hline
\end{tabular}

Table 3 Mean ( \pm s.d.) effects of dietary lipid saturation on dry matter feed intake, apparent digestibility coefficients and the apparent metabolisable energy content of diets fed to laying hens at 42 weeks of age

\begin{tabular}{|c|c|c|c|c|c|c|}
\hline & Control & $\begin{array}{c}\text { Poly- } \\
\text { unsaturated } \\
\text { (n-3) }\end{array}$ & $\begin{array}{c}\text { Poly- } \\
\text { unsaturated } \\
\text { (n-6) }\end{array}$ & $\begin{array}{c}\text { Mono- } \\
\text { unsaturated } \\
\text { (n-9) }\end{array}$ & Saturated & Significance \\
\hline Feed intake (g/bird/day) & $100.2 \pm 5.5$ & $100.5 \pm 10.4$ & $101.8 \pm 5.2$ & $105.4 \pm 2.7$ & $102.4 \pm 3.0$ & $\mathrm{NS}^{1}$ \\
\hline Organic matter (\%) & $74.7 \pm 1.3$ & $75.8 \pm 0.6$ & $74.8 \pm 0.6$ & $74.8 \pm 1.0$ & $75.6 \pm 0.8$ & $\mathrm{NS}^{1}$ \\
\hline Crude protein (\%) & $56.5^{\mathrm{ab}} \pm 2.7$ & $56.3^{\mathrm{ab}} \pm 1.7$ & $55.0^{\mathrm{b}} \pm 1.8$ & $58.4^{\mathrm{a}} \pm 1.3$ & $57.9^{\mathrm{ab}} \pm 1.6$ & $*$ \\
\hline Fat (\%) & $94.5^{\mathrm{a}} \pm 1.3$ & $94.2^{\mathrm{a}} \pm 2.0$ & $95.6^{\mathrm{a}} \pm 1.2$ & $94.8^{\mathrm{a}} \pm 0.7$ & $90.4^{b} \pm 1.8$ & $* * *$ \\
\hline $\mathrm{AME}^{2}$ & $13.0^{\mathrm{b}} \pm 0.2$ & $13.3^{\mathrm{a}} \pm 0.2$ & $12.9^{b} \pm 0.1$ & $13.2^{\mathrm{ab}} \pm 0.2$ & $13.1^{\mathrm{ab}} \pm 0.1$ & $* *$ \\
\hline $\mathrm{AME}_{\mathrm{n}}^{3}$ & $12.4^{\mathrm{b}} \pm 0.2$ & $12.7^{\mathrm{a}} \pm 0.2$ & $12.4^{\mathrm{b}} \pm 0.1$ & $12.6^{\mathrm{ab}} \pm 0.2$ & $12.5^{\mathrm{ab}} \pm 0.1$ & $* *$ \\
\hline
\end{tabular}

\footnotetext{
${ }_{\mathrm{a}, \mathrm{b}, \mathrm{c}}$ Row means with different superscripts differ significantly at * $P<0.05$; ** $P<0.01$; *** $P<0.0001$

${ }^{1}$ Non significant differences $(P \geq 0.05)$

${ }^{2}$ Apparent metabolisable energy $(\mathrm{MJ} / \mathrm{kg})$

${ }^{3}$ Apparent metabolisable energy corrected for nitrogen retention (MJ/kg)
}

be digested, whereas SFAs have an inferior ability to form micelles because of their characteristic low polarity (Wiseman \& Lessire, 1987). This characteristic of SFAs would increase the viscosity of digesta in 
the gastrointestinal tract and subsequently decrease the digestion and absorption of fat. Additionally, the decrease in fat digestibility of the SFA diet was not associated with a consequent decrease in either the AME or $\mathrm{AME}_{\mathrm{n}}$, content.

The failure to establish a clear tendency between dietary lipid saturation and the recorded parameter differences, suggest that the dietary fatty acid profile is of lesser importance in establishing nutrient digestibility coefficients for laying hens, compared to other factors such as constant lipid inclusion levels, as well as isoenergetic and isonitrogenous nutrient levels of diets.

\section{Conclusion}

Results of the present study indicate that dietary lipid saturation has no significant effect on feed intake of laying hens as well as the apparent digestibility coefficients of most analysed nutrients, except in the case of crude protein, fat and AME. However, the significant negative effect of saturated fatty acids on the digestibility coefficient of fat needs further investigation to determine its consequences on production performance traits of laying hens. Additionally, the need remains to determine the digestibility coefficients of individual fatty acid methyl esters in an attempt to clarify the interaction between the carbon chain length and the AME yield of specific fatty acids.

\section{Acknowledgements}

The authors wish to acknowledge Nutri Feeds, Energy oil and Vergezocht HO oils for their technical and financial support during the trial.

\section{References}

AOAC, 2000. Official Methods of Analysis, $17^{\text {th }}$ Edition. Association of Official Analytical Chemists, Virginia, U.S.A.

Dhanoa, M.S., Lopez, S. \& France, J., 2008. Linear models for determining digestibility. In: Mathematical modelling in animal nutrition. Eds: France, J. \& Kebreab, E., pp. 12-25.

Dozier, D.A., Kerr, B.J., Corzo, A., Kidd, M.T., Weber, T.E. \& Bregendahl, K., 2008. Apparent metabolisable energy of glycerine for broiler chickens. Poult. Sci. 87, 317-322.

Folch, J., Lees, M. \& Sloane-Stanley, G.H., 1957. A simple method for the isolation and purification of total lipids from animal tissue. J. Biol. Chem. 226, 497-509.

Honda, K., Kamisoyama, H., Isshiki, Y. \& Hasegawa, S., 2009. Effects of dietary fat levels on nutrients digestibility at different sites of chicken intestines. J. Poult. Sci. 46, 291-295.

Jorgensen, H., Zhao, X.Q., Theil, P.K. \& Jakobsen, K., 2008. Effect of graded levels of rapeseed oil in isonitrogenous diets on the development of the gastrointestinal tract and utilisation of protein, fat and energy in broiler chickens. Arch. Anim. Nutr. 62 (4), 331-342.

Larbier, M. \& Leclercq, B., 1994. Nutrition and Feeding of Poultry. Translated by J. Wiseman; Nottingham University Press, Loughborough Leicestershire, UK. pp. 47-74.

Leeson, S. \& Summers, J.D., 2001. Nutrition of the Chicken. $4^{\text {th }}$ Edition. University Books, Guelph, Ontario, Canada. pp. 14-29; 91-94.

Mateos, G.G. \& Sell, J.L., 1980. Influence of graded levels of fat on utilization of pure carbohydrate by the laying hen. J. Nutr. 110, 1894-1904.

SAS, 2010. Statistical analysis system (SAS ${ }^{\circledR}$ ) user's guide. Version 6.12. SAS Institute Inc. Cary, NC, USA.

Smink, W., Gerrits, W.J.J., Hovenier, R., Geelen, M.J.H., Lobee, H.W.J., Verstegen, M.W.A. \& Beynen, A.C., 2008. Fatty acid digestion and deposition in broiler chickens fed diets containing either native or randomized palm oil. Poult. Sci. 87, 506-513.

Wiseman, J. \& Lessire, M., 1987. Interactions between fats of differing chemical content: Apparent metabolisable energy values and apparent fat digestibility. Br. Poult. Sci. 28, 663-676.

Zollitsch, W., Knaus, W., Aichinger, F. \& Lettner, F., 1997. Effects of different dietary fat sources on performance and carcass characteristics of broilers. Anim. Feed Sci. Technol. 66, 63-73. 